\title{
Assessing the legislative and regulatory framework supporting the management of records in South Africa's public health sector
}

\begin{tabular}{|c|c|}
\hline \multicolumn{2}{|c|}{$\begin{array}{l}\text { Authors: } \\
\text { Shadrack Katuu }{ }^{1,2} \\
\text { Thomas van der Walt }{ }^{1}\end{array}$} \\
\hline \multicolumn{2}{|c|}{$\begin{array}{l}\text { Affiliations: } \\
{ }^{1} \text { Department of Information } \\
\text { Sciences, University of } \\
\text { South Africa, South Africa }\end{array}$} \\
\hline \multicolumn{2}{|c|}{$\begin{array}{l}{ }^{2} \text { Head of Records Unit, } \\
\text { International Atomic } \\
\text { Energy Agency, Austria }\end{array}$} \\
\hline \multicolumn{2}{|c|}{$\begin{array}{l}\text { Corresponding author: } \\
\text { Shadrack Katuu, } \\
\text { skatuu@gmail.com }\end{array}$} \\
\hline \multicolumn{2}{|c|}{$\begin{array}{l}\text { Dates: } \\
\text { Received: } 25 \text { Apr. } 2015 \\
\text { Accepted: } 17 \text { Sept. } 2015 \\
\text { Published: } 13 \text { May } 2016\end{array}$} \\
\hline \multicolumn{2}{|c|}{$\begin{array}{l}\text { How to cite this article: } \\
\text { Katuu, S. \& Van der Walt, T., } \\
2016, \text { 'Assessing the } \\
\text { legislative and regulatory } \\
\text { framework supporting the } \\
\text { management of records in } \\
\text { South Africa's public health } \\
\text { sector', South African Journal } \\
\text { of Information Management } \\
\text { 18(1), a686. http://dx.doi. } \\
\text { org/10.4102/sajim.v18i1.686 }\end{array}$} \\
\hline \multicolumn{2}{|c|}{$\begin{array}{l}\text { Copyright: } \\
\text { (c) 2016. The Au } \\
\text { Licensee: AOSIS } \\
\text { licensed under } \\
\text { Commons Attrit } \\
\text { License. }\end{array}$} \\
\hline \multicolumn{2}{|l|}{ Read online: } \\
\hline 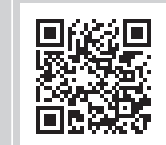 & $\begin{array}{l}\text { Scan this QR } \\
\text { code with your } \\
\text { smart phone or } \\
\text { mobile device } \\
\text { to read online. }\end{array}$ \\
\hline
\end{tabular}

Background: The process of improving the quality of health care delivery requires that health systems function efficiently and effectively. A key component of health care systems' efficiency is the administration of records that are often poorly managed. Any improvement in the management of records has to be done in full cognisance that records are generated in an organisational setting and based on a national legislative and regulatory framework.

Objectives: The purpose of this article is to assess the contextual legislative and regulatory framework of South Africa's health care system and its impact on the effectiveness of records management in public health care institutions.

Method: Data for the study were obtained from two sources. On the one hand, the study conducted a review of literature that not only provided background information but also informed the research process. On the other hand, a varied number of respondents were identified through purposive sampling, and their expert knowledge solicited through semi-structured interviews.

Results: The literature review, as well as the interviews, revealed that findings on the legislative and regulatory environment are multi-layered. For instance, respondents echoed observations made from the literature review that, whilst South Africa had a complex array of legal instruments, compliance levels at public health institutions were very rudimentary and contrary to the levels of sophistication expected by the legal instruments. A number of respondents noted the lack of specific guidelines for health records and that in most government departments there was 'a very low key focus on the regulatory issues'. Several respondents stated that even when there were general guidelines for managing records, very few public institutions were compliant. A majority of the respondents noted a lack of an integrated approach in the different legislative and regulatory instruments, for instance, on the issue of records retention.

Conclusion: The study revealed three related observations: firstly, that there is substantial legislative and regulatory dissonance in the management of health records in the country's public health sector; secondly, understanding the complex interplay of different legal and regulatory instruments in the country's public health sector is a critical first step, but it remains the beginning of the process; thirdly, there are lessons to be drawn from the extensive experiences of other countries such as the United Kingdom in addressing the legislative and regulatory challenges.

\section{Introduction}

Jonas, Goldsteen and Goldsteen (2007:9) argue that health is the product of multiple factors including 'genetic inheritance, the physical environment, and the social environment, as well as an individual's behavioural and biologic response to these factors'. The central focus of health care systems is to restore health or prevent exacerbation of health problems. Any nation's health care system is influenced by both external and internal factors. The combined interaction of these internal and external forces determines the quality of health care delivered.

The process of improving the quality of health care delivery requires that health systems function efficiently and effectively. A key component of health care systems functioning effectively is the management of records. Several studies in South Africa have demonstrated that if health facilities are to provide quality services then they need efficient record management programmes (Brink 2004; Katuu 2015a; Mahoro 2013; Marutha 2011). 


\section{Problem Statement}

The provision of health care in any country is often one of the most fundamental rights of its citizens. In South Africa, the right to health is enshrined in Chapter 2 of the Constitution. However, throughout South Africa's history, both during its colonial period and apartheid era, the racial segregation that permeated every aspect of the country was also reflected in the health system. At the dawn of South Africa's new political dispensation in 1994 there was great expectation that there would be greater equity in all aspects of life, including the provision of health services. By 1996 the national Health Department had acknowledged the continuing inequality in health expenditure in the country (Harrison, Barron \& Edwards 1996:xv). The private sector, for example, accounted for approximately $60 \%$ of resources spent on health for about $20 \%$ of the population. Within the public sector there was also gross inequity in per capita spending amongst the provinces (Ngwena \& Cook 2005:127-130). In addition, a disproportionate amount of resources was spent on tertiary health care as opposed to primary health care (Harrison et al. 1996:xv). The distribution, physical state and functional design of facilities in the public sector needed to serve the majority of the citizens in the new nation was gravely inadequate.

\section{Research objective}

The key to transforming any society often begins with reviewing its legislative and regulatory framework and this is particularly critical in the health sector. Legislative reforms have been the subject of debates all over the world, from the US with the Affordable Care Act to the UK's reform of the National Health Service (Dusheiko 2014; Sommers, Kenney \& Epstein 2014). Considering South Africa's quest for transformation of the public health sector, the assessment of the legislative and regulatory framework is foundational to eventual success of the transformation process (Whiteside 2014). A number of media reports have highlighted the negative effects of poor records management in South Africa's public health sector. This was demonstrated in the case where the health records of a former Minister of Health in South Africa were published in a weekend newspaper. The Minister sued 'the editor, two journalists, and the publisher of the Sunday Times for allegedly violating her right to privacy' by obtaining and disclosing her health records without her consent (Berger, Hassim, Heywood, Honermann, Krynauw \& Rugege 2013:33; De Lange \& Caelers 2007). There have been a number of cases of negligence within the health sector that have resulted in the maiming or death of patients (Slabbert 2011:108-109; Walker, Darer, Elmore \& Delbanco 2014). Whilst in most cases probes have been launched in order to curb the acts of negligence, in one sad case not even an investigation could be launched into the case of the death of a baby because the deceased's records could not be found (Khoza 2008). In this regard, this study assessed the legislative and regulatory framework in South Africa and its impact on the management of records in public health institutions.

\section{Literature review}

The history of South Africa's health sector is intricately connected to the history of the country. For many decades, events within the health sector have, either directly or indirectly, contributed to the national narrative. For example, during the Soweto uprising of 1976, it was the hospital in Soweto that became the epicentre of interest from national and international media who, not having eye witness evidence from the school children protests and subsequent shooting by police forces, went to the hospital to verify the evidence of the police brutality (Ndlovu 2006:343-349).

Over the period of its long history, the governance of the country's health system had been both inequitable and fragmented. The inequity was most obvious in the racially divided health system during the apartheid period, whose vestiges are still very evident almost two decades since apartheid was officially dismantled (South Africa Department of Health 2010:5). During the apartheid period, the health system consisted of 14 different operating health authorities, ten in the Homelands and the other four in what was known as White South Africa. The legacy of this fragmentation is a system divided into two parallel sectors 'a public sector financed through general taxation for the majority and a private sector' (Schneider, Barron \& Fonn 2007:290). Whilst the majority of the population accessed a weak and dysfunctional public system, a few privileged people accessed a very strong private health sector. The private sector included health professionals in private practice, private hospitals, pharmaceutical manufacturers and distributors and Medical Aid Schemes (Cullinan 2006:3).

According to Schneider et al. (2007:294), the new administration in 1994 inherited a reasonably well-resourced health system, able to offer quality services to segments of the population. However, it was also deeply inequitable, disorganised and inefficient, with powerful private sector interests and limited institutional intelligence in the form of knowledge and information to plan restructuring of the health sector (Thiede \& Mutyambizi 2010:192). To this end, the new democratic government sought to consolidate the fragmented health authorities. In addition, the health services were 'doctor-dependent medical services biased towards curing existing diseases (i.e. providing medical care) rather than preventing disease (through provision of services such as clean water and sanitation and education)' (Cullinan 2006:3). The new government sought to reorient the doctor dependence towards preventive health and to widen their services to all the population through the public health system.

The democratic changes that took place in the 1990s necessitated drastic legislative, regulatory and organisational changes to address the inequity. The legislative and regulatory aspects are the core of this discussion. South Africa has a 'hybrid' or 'mixed' legal system, formed by the interweaving of three distinct legal traditions (Du Bois 2004:9-16). The first legal tradition is a civil law system inherited from the Dutch 
and commonly referred to as Roman Dutch law, which draws from two sources: 'judicial decisions and the writing of the old Dutch jurists' (Madhuku 2010:50). The second legal tradition is a common law system inherited from the British, and the third a customary law system inherited from indigenous Africans and is often termed as African Customary Law (Alberts \& Mollema 2014; Du Bois 2010). These traditions have had complex interrelationships with each other, causing areas of strain in the past, not only in South Africa but also other parts of the African continent (Toufayan 2014). The complexity of the interrelationships has contributed to making it difficult to efficiently address transformation of the legacy of the deeply inequitable, disorganised and inefficient system.

In South Africa, the Constitution's Sections 27 and 28 embodies the inalienable rights to health for all South Africans. In addition, children have the right to basic nutrition, shelter and social services (South Africa 1996a). According to the Constitution, health is a 'concurrent' function of both national and provincial spheres of government with the national government largely responsible for setting policies and provinces largely responsible for implementing these policies (Cullinan 2006:3). The current National Health Act was promulgated in 2003 and further elaborates how the Constitutional rights can be accessed. It provides 'a framework for a structure uniform health system within the Republic, taking into account the obligations imposed by the Constitution and other laws on the national, provincial and local governments with regard to health services' (South Africa 2003:2).

Within the context of continuously striving for transformation in the public health sector, it is worth exploring the extent to which records in public health institutions have been managed. There have been a number of media reports illustrating instances of poor records management. These reports paint a gloomy picture of the extent to which records in public health institutions are managed. This leads to the fundamental question of the extent to which legislative and regulatory instruments are providing guidance in the management of records in supporting the fulfilment of the constitutional rights of South Africa's citizens. Therefore, this study sought to explore the current state of the legislative and regulatory framework in order to support the management of records in the country's public health care institutions.

\section{Research methodology}

This research study was conducted at two levels: first, review of literature and second, the interviewing of 22 respondents from different professional backgrounds in three main sectors: the public health sector, the private health sector as well as those in academic and research institutions.

The review of literature not only provided a background to the study, it also informed as well as actively fashioned the discussions throughout the research process. The literature review process informed the framing of the interview questions for the respondents as well as contextualising the kinds of responses received from the interviewees.

The interview questions were semi-structured and sought for information from respondents about their practical experience with legislative and regulatory instruments. This information included the impact of the legal and regulatory framework on the management of records in public health care instruments touching on issues such as retention and disposition, privacy as well as soliciting information on future trends based on global developments.

The professional backgrounds of the respondents were deliberately diverse in order to solicit varied perspectives that would demonstrate the nuanced understandings required to understanding the complex dynamics in the health sector, as well as within the records management profession in South Africa.

\section{Data analysis and research findings}

Findings on the legislative and regulatory environment were multi-layered. The literature review revealed that South Africa's legislative terrain is complex. There are two categories of legislative instruments. The first category oversees the management of records within the health sector. The fundamental act at the heart of the country's health framework is the National Health Act which stipulates that a health record should be 'created and maintained at that health establishment for every user of health services' and protected (South Africa 2003:ss. 13, 17). In addition, the Act adds that the Minister may make regulations on how particular records should be managed even though at the time of the study none had been published (South Africa 2003:ss. 68, 90). Additional legislative instruments within the health sector include:

- Academic Health Centres Act 86 of 1993

- Allied Health Professions Act 63 of 1982

- Choice on Termination of Pregnancy Act 92 of 1996

- Council of Medical Schemes Levy Act 58 of 2000

- Dental Technicians Act 19 of 1979

- Foodstuffs, Cosmetic and Disinfectants Act 54 of 1972

- Hazardous Substances Act 15 of 1973

- Medical Schemes Act 131 of 1998

- Medicines and Related Substances Act 101 of 1965

- Mental Health Care Act 17 of 2002

- Nursing Act 33 of 2005

- Occupational Diseases in Mines and Works Act 78 of 1973

- Pharmacy Act 53 of 1974 as amended (South Africa, 1974)

- Sterilisation Act 44 of 1998

- Tobacco Products Control Amendment Act 63 of 2008

Each of these instruments is expected to address the management of records within its own context.

The second category of legislative instruments oversees different aspects of the management of records in the public 
sector and therefore encompasses the health sector. These include: the National Archives Act 43 of 1996 (South Africa 1996b), the Electronic Communications and Transactions Act 25 of 2002 (South Africa 2002), the Promotion of Access to Information Act 2 of 2000 (South Africa 2000), the Protection of Personal Information Act 4 of 2013 (South Africa 2013), and the Protection of Information Act 84 of 1982 (South Africa 1982).

Both the Promotion of Access to Information Act (PAIA) and the Protection of Personal Information Act (POPIA) have made special mention of health records. PAIA, which facilitates access to records, notes that access to health records should be done to ensure that the disclosure does not 'cause serious harm' to the physical or mental health, or well-being of the requester (South Africa 2000:s. 30). POPIA, which regulates the processing of personal information by both public and private institutions, notes that health information is considered a special kind of personal information and has to be managed effectively (South Africa 2013, s. 32).

One of the respondents argued that, whilst South Africa had put together a number of 'very sophisticated legislative instruments which were comparable to those in any country in the world', the compliance levels at health institutions were very rudimentary and contrary to the levels of sophistication expected by the legal instruments. A number of respondents attributed this poor compliance to the lack of awareness of the legislative provisions dealing with the management of records. This was most apparent when health institutions received PAIA requests and could not provide access to records, in part, because of their poor records management systems.

In addition, the respondents also noted a lack of an integrated approach in the different legislative instruments, for instance, on the issue of records retention. Many acts did not specify retention periods for records and the few that did would often appear contradictory. According to the respondents, most health institutions did not have a common understanding of how long records could be kept. For instance, one of the respondents had spoken with key managers at health institutions who believed records should be kept for five years but did not have a legal or procedural basis for this view, except that this was information passed on from their predecessors. Other respondents argued that either the Archives Act or the Health Act stated that certain records, for instance X-rays, had to be kept for five years or 15 years. However, the relevant acts did not specify any of these periods thus demonstrating the extent of the discrepancy amongst some of the respondents.

Whilst the legislative environment could be considered extensive and well structured, the regulatory framework was less structured but complex nonetheless. The literature revealed that, whilst there were numerous regulations within the health sector, very few provided detailed guidance on the management of records. For instance, there are five documents outlining Standard Operating Procedures for
District Health Information System (DHIS) that record data about facility services as well as infrastructure and human resources at the primary care level. Three of those are: facility level (South Africa Department of Health 2012), subdistrict level (South Africa Department of Health 2013d), and district level (South Africa Department of Health 2013a), which state that patient records need to be filed, warn against inaccuracy and duplication of the records and prescribe for their safe storage. The two additional standard operating procedures are: the provincial level (South Africa Department of Health 2013c) and national level (South Africa Department of Health 2013b). These procedures require that all staff, supervisors, line and programme managers involved in information management have relevant levels of knowledge and skills in the management of paper and electronic records. However, none of these regulations provide definitions, processes and methodologies required to manage these health records. They also do not provide a breakdown of the aspects that would constitute 'relevant levels of knowledge and skills' for the staff.

Beyond the national Department of Health, the most comprehensive guidelines for records in the health sector were developed by the Health Professions Council of South Africa (HPCSA) and published in three editions between 2002 and 2008 (Health Professions Council of South Africa 2002; Health Professions Council of South Africa 2007; Health Professions Council of South Africa 2008). The guidelines provided a definition of the health records, what they constitute and how they should be managed, addressing aspects such as storage, ownership as well as access. Several respondents stated that even when there were general guidelines for managing records, very few public institutions were compliant.

The literature revealed that the National Archives did not have specific guidelines for health records, but the institution had published regulatory guidance on the management of records in the form of Advisory Pamphlets (AP) that provide general, rather than specific, guidance to the health sector. AP no. 1 addressed the management of public records (National Archives and Records Service of South Africa 2007c), AP no. 2 addressed the management of electronic records (National Archives and Records Service of South Africa 2007a) and AP no. 3 outlined the responsibilities of records professionals within a public institution and the prerequisite qualifications and experience for them to be appointed (National Archives and Records Service of South Africa 2007b). All the regulatory guidance from the National Archives remained very general rather than specific to the health sector. One respondent noted that the National Archives had little direct contact with health institutions, whilst another respondent argued that the National Archives was a weak institution and could not impose compliance.

Similar to the case of legislative instruments, there was a lack of uniformity on the issue of retention and disposal of records in regulatory instruments. This was most evident in 
TABLE 1: Retention periods for different categories of health records.

\begin{tabular}{|c|c|}
\hline Type of record & Retention period \\
\hline Most health records & $\begin{array}{l}\text { Stored for a period of } 6 \text { years 'from } \\
\text { the date they become dormant' }\end{array}$ \\
\hline $\begin{array}{l}\text { Records belonging to individuals under } \\
\text { the age of } 18 \text { and obstetric records }\end{array}$ & $\begin{array}{l}\text { Stored until the individual reaches } \\
\text { the age of } 21\end{array}$ \\
\hline Records of mentally incompetent patients & Stored for the duration of their life \\
\hline $\begin{array}{l}\text { Records related to the Occupational } \\
\text { Health and Safety Act }\end{array}$ & $\begin{array}{l}\text { Stored for } 20 \text { years subsequent to } \\
\text { patient receiving treatment }\end{array}$ \\
\hline Records related to the exposure to asbestos & Stored for 25 years or more \\
\hline
\end{tabular}

guidelines issued by the HPCSA as summarised in the table above (Health Professions Council of South Africa 2008:4).

As shown in Table 1, most health records should be stored for a period of six years or more 'from the date they became dormant' (Health Professions Council of South Africa 2008:4). This requirement suggests that records have to be continuously monitored in order to determine when they initially become dormant and, from that point on, kept for at least six years. The additional challenge, which is already arduous to address, is monitoring the specific categories of records that differ from the general rule.

Several respondents echoed this lack of consistency on retention periods for similar health records, drawing from their varied experiences and knowledge. Not only did their views on retention periods of specific records vary vastly from one other, often they also failed to link their views with precise legal or regulatory provisions. This suggested that their views may have been developed through tradition, the result of lacking clear guidelines for the health sector. For two of the respondents, the responsibility for the development of retention and disposal guidelines lay directly on the national and provincial archival institutions. Some respondents noted that, historically, there had been records retention guidelines for hospitals in the Transvaal Provincial Administration, but these had not been updated. One respondent argued that, because of the confusing nature of retention and disposal requirements, some health institutions had resorted to keeping everything indefinitely. However, this came with huge cost implications related to space, equipment and human resources and resulted in poor access to health records when required for clinical activities. In addition, records with historical value need to be managed in archival institutions that undergo archival processing, including appraisal, arrangement and description in order to facilitate provision of records access to a wider audience beyond just the health institution (Katuu 2015b; Williams 2006).

Finally, discussions with respondents revealed that the issue of retention and disposal also needed to address discrepancies when the same type of record in a health institution existed in different formats (i.e. hard copy and digital). For one respondent, this was exemplified by the challenge of keeping digital x-rays, yet film copies also existed. The respondent added that the challenge of longterm preservation of digital records would be whether or not to retain digital copies. In this regard, a review of literature revealed that long-term preservation of digital records was a complex subject, one that required concerted efforts in order to be fully addressed (Brown, Katuu, Sebina \& Seles 2009:3346; Katuu 2012; Katuu \& Ngoepe 2015).

\section{Conclusions and recommendations}

There are three concluding remarks that were drawn from the research process. First, there is substantial legislative and regulatory dissonance in the management of health records in the country. South Africa has more than 200 years of legislative history in the health sector with the current legislative and regulatory instruments straddling both the apartheid and post-apartheid eras. Whilst there are extensive legislative and regulatory instruments that could facilitate the management of records in the health sector, a considerable number lack strategic coherence as a result of their legacy. For instance, the retention period for health records is not substantially addressed in current legislative or regulatory instruments within the ambit of the National Archives or any national or provincial Department of Health.

Second, understanding the complex interplay of different legal and regulatory instruments in the country's public health sector is a critical first step, but it remains the beginning of the process. One respondent acknowledged that, over time, the public sector had evolved from being ignorant of legislative instruments. The respondent added:

'Nine years ago nobody knew about these laws and nobody cared. Then they did know and they didn't care. And then they did know and did care but they didn't know what to do about it. Now they do know and they do care and they are saying help. That's a big change' (Respondent no. 8)

However, beyond having a sophisticated understanding of the legislative and regulatory instruments, there is need for an equally sophisticated implementation process. This means that knowledge of the instruments has to be translated to practice through compliance in order to ultimately improve the quality of health services. For a number of respondents, effective records management in the health sector was intricately linked to compliance. According to one of the respondents:

Records compliance is the backbone of all the other compliance. For .... health care institution or anyone in the public sector, if you want to comply with the Public Finance Act or the Municipal Finance Act, whichever level you are, then it's very difficult to comply with it without having proper records systems (Respondent no. 6)

Third, there are lessons to be drawn from the extensive experiences of other countries. For instance, between 2006 and 2009, the UK National Health Service published two parts of the Code of Practice for Records Management which included: guidelines, responsibilities and processes of managing records as well as details on records retention and disposal schedules for the different kinds of health, as well as business and corporate records (GB. Department of Health 2006; GB. Department of Health 2009). The strength of the Code of Practice is that it is based on both legal requirements 
as well as professional best practice (GB. Department of Health 2006:1). It draws on 'advice and published guidance available from the Ministry of Justice and The National Archives as well as from best practices followed by a wide range of organisations in both the public and private sectors' (GB. Department of Health 2006:3). In addition, the Code of Practice is part of a larger framework of an information governance policy and implementation toolkit (GB. Department of Health 2006:3-4) that is necessary to meet the requirements set out under the Data Protection Act 1998 (GB. Parliament 1998) and the Freedom of Information Act 2000 (GB. Office of Public Sector Information 2000). As an example for South Africa, this code of practice ensures there is increased legal and regulatory certainty for health institutions by providing components that include:

- A model records management policy.

- A model records management strategy.

- A records inventory survey template.

- An approach to records management audit.

- Electronic records inventory form definitions.

- Electronic records inventory survey form.

- Manual records inventory form definitions.

- Manual records inventory survey form.

- Raising the profile of records management - 'getting started'.

- The Roadmap Framework (Great Britain, Department of Health [United Kingdom] 2014).

The lesson to be drawn is that legislative and regulatory certainty on the management of records requires adequately defined roles, responsibilities and obligations of both public entities and the managers that run them.

In conclusion, this research study has revealed that whilst a number of sophisticated legislative instruments and a few regulatory instruments exist in the health sector, they do not comprehensively address the needs within health institutions. In addition, the health sector instruments are largely divorced from those addressing records management in the wider public sector. For this trend to be reversed a lot of work needs to be done to address the legislative and regulatory dissonance and there are lessons to be learnt from the experiences of other countries. The changes are not only required within the health sector but across the public sector in general (Ngoepe 2013:167).

\section{Acknowledgements Competing interests}

The authors declare that they have no financial or personal relationships which may have inappropriately influenced them in writing this article.

\section{Authors' contributions}

S.K. conducted the research as part of his doctoral studies under the supervision of T.W.

\section{References}

Alberts, M. \& Mollema, N., 2014, 'Developing legal terminology in African languages as aid to the court interpreter: A South African perspective', Lexikos 23(1), 29-58.

Berger, J., Hassim, A., Heywood, M., Honermann, B., Krynauw, M. \& Rugege, U. (eds.), 2013, The National Health Act 61 of 2003 - A guide, Siber Ink, Cape Town.

Brink, I., 2004, Records management in health Institutions: A Department of Health project - North West Province, South Africa, Johannesburg, viewed 27 August 2015, from http://esarbica.com/ESARBICAnews2.pdf

Brown, A., Katuu, S., Sebina, P. \& Seles, A., 2009, Module 4: Preserving electronic records, International Records Management Trust, London, viewed 02 November 2014 , from http://www.irmt.org/documents/educ training/term $\% 20$ modules/ IRMT\%20TERM\%20Module\%204.pdf

Cullinan, K., 2006, 'Health Services in South Africa: A Basic Introduction', Health-e News Service, Cape Town, viewed 27 August 2015, from http://www.health-e.org. za/wp-content/uploads/2013/04/Health_services_briefing_doc.pdf

De Lange, D. \& Caelers, D., 2007, 'Missing Manto Records baffle Clinic', IOL News, Cape Town, viewed 27 August 2015, from http://mobi.iol.co.za/\#!/article/missingmanto-records-baffle-clinic-1.366413

Du Bois, F., 2004, 'Introduction: History, system and sources', in C.G. Van der Merwe \& J.E. Du Plessis (eds.), Introduction to the Law of South Africa, pp. 1-54, Kluwer law international, The Hague.

Du Bois, F., 2010, 'State liability in South Africa: A constitutional remix', Tulane European \& Civil Law Forum 25, 139-172.

Dusheiko, M., 2014, 'Patient choice and mobility in the UK health system: Internal and external markets', in R. Levaggi \& M. Montefiori (eds.), Health Care Provision and Patient Mobility, pp. 81-132, Springer, Milan.

Great Britain. Department of Health, 2006, Records Management: NHS Code of Practice Part 1, Department of Health, London, viewed 27 August 2015, from https://www.gov.uk/government/uploads/system/uploads/attachment data/ $\mathrm{https}$ ///WwW.gov.uk/government/uploads/system/uploads/attachment_da
file/200138/Records_Management_-_NHS_Code_of_Practice_Part_1.pdf

Great Britain. Department of Health, 2009, Records Management: NHS Code of Practice Part 2, Department of Health, London, viewed 27 August 2015, from Practice Part 2, Department of Health, London, viewed 27 August 2015, from file/200139/Records Management__NHS_Code_of Practice_Part_2 second file/200139/Re

Great Britain. Department of Health, 2014, NHS Records Management, Department of Health, London, viewed 27 August 2015, from http://www.connectingforhealth nhs.uk/systemsandservices/infogov/records

Great Britain. Office of Public Sector Information, 2000, Freedom of Information Act 2000 , The Stationery Office, London.

Great Britain. Parliament, 1998, Data Protection Act of 1998, 1st March 2010 edn., The Stationery Office, London.

Harrison, D., Barron, P. \& Edwards, J., 1996, 'Preface', in South African Health Review, pp. ix-x, Health Systems Trust, Durban. http://dx.doi.org/10.1017/ cbo9780511523625.001

Health Professions Council of South Africa, 2002, Guidelines on the keeping of patient records - Booklet 11, Health Professions Council of South Africa, Pretoria, viewed 27 August 2015, from http://www0.sun.ac.za/ruralhealth/ukwandahome/ rudasaresources 2009/More/Guidelines\%200n\%20Keeping\%20 of\%20 Patient $\% 27 \mathrm{~s} \% 20$ Records.pdf

Health Professions Council of South Africa, 2007, Guidelines on the keeping of patient records - Booklet 15, Health Professions Council of South Africa, Pretoria, viewed 27 August 2015, from http://www.hpcsa.co.za/downloads/conduct_ethics/rules/ guidelines_patient.pdf

Health Professions Council of South Africa, 2008, Guidelines on the keeping of patient records - Booklet 14, Health Professions Council of South Africa, Pretoria, viewed 27 August 2015, from http://www.hpcsa.co.za/downloads/conduct_ethics/rules/ generic_ethical_rules/booklet_14_keeping_of_patience_records.p $\overline{d f}$

Jonas, S., Goldsteen, R. \& Goldsteen, K., 2007, Introduction to the US Health Care system, Springer Publishing Company, New York.

Katuu, S., 2012, 'Enterprise content management and digital curation applications Maturity Model Connections', paper presented at the The Memory of the World in the Digital Age: Digitization and Preservation Conference, Vancouver in the Digital Age: Digitization and Preservation Conference, Vancouver, new/fileadmin/MULTIMEDIA/HQ/Cl/Cl/pdf/mow/VC_Katuu_28_D_1130.pdf

Katuu, S., 2015a, 'Managing records in South African public health care institutions: A critical analysis', PhD thesis, University of South Africa.

Katuu, S., 2015b, 'User studies and user education programmes in archival institutions', Aslib Journal of Information Management 67(4), 442-457. http://dx.doi. org/10.1108/AJIM-01-2015-0005

Katuu, S. \& Ngoepe, M., 2015, 'Managing digital records within South Africa's legislative and regulatory framework', paper presented at the 3rd International Conference on Cloud Security and Management ICCSM-2015, Tacoma, WA viewed n.d., from http://academic-conferences.org/iccsm/iccsm2015/iccsm15home.htm

Khoza, T., 2008, 'Dead Baby's Records Missing', News24, viewed 27 August 2015, from http://www.news24.com/SouthAfrica/News/Dead-babys-records-missing20080707

Madhuku, L., 2010, An introduction to Zimbabwean law, Weaver Press, Harare.

Mahoro, A., 2013, 'Examining the inventory management of antiretroviral drugs at community health centres in the Cape Metropole, Western Cape', Masters thesis, University of the Western Cape. 
Marutha, N.S., 2011, 'Records management in support of service delivery in the public health care sector of the Limpopo Province in South Africa', Masters thesis, University of South Africa.

National Archives and Records Service of South Africa, 2007a, Advisory pamphlet no 2: Electronic records and the law: What governmental bodies need to know National Archives and Records Service of South Africa, Pretoria, viewed 27 August 2015, from http://www.national.archives.gov.za/Advisory\%20Pamplet $\% 20$ No $\% 202 \% 20$ April $\% 202012$.pdf

National Archives and Records Service of South Africa, 2007b, Advisory pamphlet no 3: Records managers and the law: What governmental bodies need to know National Archives and Records Service of South Africa, Pretoria, viewed 27 August 2015, from http://www.national.archives.gov.za/rms/ad_pamphlet3.PDF

National Archives and Records Service of South Africa, 2007c, Advisory pamphlet no. 1: Managing Public Records and the Law: What governmental bodies need to know, National Archives and Records Service of South Africa, Pr to know, 27 August 2015, from http://www.nation es.gov.za/rms/ad pamphlet1.PDF

Ndlovu, S.M., 2006, 'The Soweto Uprising', in B. Magubane (ed.), The road to democracy in South Africa, vol. 2, 1970-1980, pp. 317-368, South African Democratic Education Trust, Pretoria.

Ngoepe, M., 2013, 'Fostering a framework to embed the records management function into the auditing process in the South African public sector', PhD thesis, University of South Africa.

Ngwena, C. \& Cook, R., 2005, 'Rights concerning Health', in D. Brand \& C. Heyns (eds.), Socio-economic rights in South Africa, Pretoria University of Law Press, Pretoria.

Schneider, H., Barron, P. \& Fonn, S., 2007, 'The Promise and the Practice of Transformation in South Africa's Health System', in S. Buhlungu, J. Daniel, R. Southall \& J. Lutchman (eds.), State of the nation: South Africa 2007, pp. 289-311, HSRC Press, Cape Town.

Slabbert, M.N., 2011, Medical Law in South Africa, Kluwer Law International, Bedfordshire.

Sommers, B.D., Kenney, G.M. \& Epstein, A.M., 2014, 'New evidence on the Affordable Care Act: Coverage impacts of early Medicaid expansions', Health Affairs 33(1), 78-87. http://dx.doi.org/10.1377/hlthaff.2013.1087

South Africa, 1974, Pharmacy Act (Act 53 of 1974), Government Printer, Pretoria.

South Africa, 1982, Protection of Information Act (Act 84 of 1982), Government Printer, Pretoria.

South Africa, 1996a, Constitution of the Republic of South Africa (Act 108 of 1996) Government Printer, Pretoria.

South Africa, 1996b, National Archives Act (Act 43 of 1996), Government Printer Pretoria.

South Africa, 2000, Promotion of Access to Information Act (Act 2 of 2000), Government Printer, Pretoria.
South Africa, 2002, Electronic Communications and Transactions Act (Act 25 of 2002), Government Printer, Pretoria.

South Africa, 2003, National Health (Act 61 of 2003), Government Printer, Pretoria.

South Africa, 2013, Protection of Personal Information Act (Act 4 of 2013), Government Printer, Pretoria.

South Africa. Department of Health, 2010, National Service Delivery Agreement: A long and healthy life for all South Africans, Department of Health, Pretoria, viewed 07 March 2014, from http://www.hst.org.za/sites/default/files/NSDA_ booklet.pdf

South Africa. Department of Health, 2012, District Health Information System Standard Operating Procedure: Facility level, Department of Health, Pretoria, viewed 05 October 2014, from http://www.health.gov.za/docs/Policies/2014/ 5SOPFacilitylevel.pdf

South Africa. Department of Health, 2013a, District Health Information System Standard Operating Procedure: District level, Department of Health, Pretoria, viewed 05 October 2014, from http://www.health.gov.za/docs/Policies/2014/3S OPDistrictlevel29Jan2014.pdf

South Africa. Department of Health, 2013b, District Health Information System Standard Operating Procedure: National level, Department of Health, Pretoria, viewed 05 October 2014, from http://www.health.gov.za/docs/Policies/2014/1S OPNationallevel27Jan2014.pdf

South Africa. Department of Health, 2013c, District Health Information System Standard Operating Procedure: Provincial level, Department of Health, Pretoria, viewed 5 October 2014, from http://www.health.gov.za/docs/Policies/2014/2SO PProvinciallevel29Jan2014.pdf

South Africa. Department of Health, 2013d, District Health Information System Standard Operating Procedure: Sub-District Level, Department of Health, Pretoria, viewed 05 October 2014, from http://www.health gov.za/docs/Policies/2014/4s OPSubdistrict29Jan2014.pdf

Thiede, M. \& Mutyambizi, V., 2010, 'South Africa', in A.S. Preker, P. Zweifel, P. \& O.P. Schellekens (eds.), Global marketplace for private health insurance: strength in numbers, World Bank, Washington.

Toufayan, M., 2014, 'When British Justice (in African Colonies) Points Two Ways: On Dualism, Hybridity, and the Genealogy of Juridical Negritude in Taslim Olawale Elias', in O. Onazi (ed.), African legal theory and contemporary problems, pp. 31-70, Springer, Dordrecht. http://dx.doi.org/10.1007/978-94-007-7537-4_3

Walker, J., Darer, J.D., Elmore, J.G. \& Delbanco, T., 2014, 'The road toward fully transparent medical records', New England Journal of Medicine 370(1), 6-8 http://dx.doi.org/10.1056/NEJMp1310132

Whiteside, A., 2014, 'South Africa's key health challenges', The ANNALS of the American Academy of Political and Social Science 652(1), 166-185. http://dx.doi. org/10.1177/0002716213508067

Williams, C. 2006, Managing archives: Foundations, principles and practice, Chandos Publishing, Oxford. http://dx.doi.org/10.1533/9781780630892 